\title{
Purification and Properties of NAD-Dependent D-Glucose Dehydrogenase Produced by Alkalophilic Corynebacterium sp. No. 93-1
}

\author{
Yoshinori KOBAYASHI ${ }^{*}$ and Koki HoRIKOSHI \\ Laboratory of Bacteriology and Ecology, The Institute of Physical \\ and Chemical Research, Wako, Saitama 351, Japan
}

Received January 24,1980

\begin{abstract}
NAD-dependent D-glucose dehydrogenase (NAD-GlcDH) was purified from the cell free extract of alkalophilic Corynebacterium sp. No. 93-1. The preparation obtained was homogeneous on disc gel and SDS-disc gel. The molecular weight of NAD-GlcDH was 51,000 by SDS-disc electrophoresis and 55,000 by gel filtration. The isoelectric point of the enzyme was $\mathrm{pH} 4.05$. The optimal pH was 9.8 , and it was stable at pH 6 to 8. NAD-GlcDH oxidized D-glucose, D-xylose, cellobiose, cellotriose, gentiobiose and laminaribiose. The $K m$ values for $\mathrm{D}$-glucose, $\mathrm{D}-\mathrm{xylose}$, cellobiose and gentiobiose were $51 \mathrm{~mm}, 125 \mathrm{~mm}, 11 \mathrm{~mm}$ and $3.2 \mathrm{~mm}$, respectively. The $\mathrm{Km}$ value for $\mathrm{NAD}$ was $0.44 \mathrm{~mm}$. The enzyme was inhibited completely by PCMB, $\mathrm{Ag}^{+}$and $\mathrm{Hg}^{2+}$. NADH had an inhibitory effect on NAD-GlcDH.
\end{abstract}

Many papers have been published on $\mathrm{D}$ glucose dehydrogenase (GlcDH) [E.C. 1.1.1.47] in microorganism and animal tissues. Especially, the properties of GlcDH of the genus Bacillus have been studied in detail in relation to spore formation. ${ }^{1 \sim 15)}$ Okamoto ${ }^{16)}$ described the purification and properties of GlcDH of Acetobacter suboxydans. Pritchard et al. ${ }^{17)}$ reported on $\mathrm{GlcDH}$ of Chlorogloeopsis fritschii. But up to now, as far as we know, there are no report on GlcDH of coryneform bacteria.

In a previous study, ${ }^{18}$, we isolated an alkalophilic Corynebacterium sp. No. 93-1 which produced NAD-dependent maltose dehydrogenase (NAD-MalDH), NADPdependent maltose dehydrogenase (NADPMalDH) and NAD-dependent D-glucose dehydrogenase (NAD-GlcDH). The purification procedures and properties of NAD-MalDH

* On leave from Meito Sangyo Co., Hachioji, Tokvo. Abbreviations: GlcDH, NAD and/or NADP-dependent D-glucose dehydrogenase; NAD-GlcDH, NAD-dependent D-glucose dehydrogenase of Corynebacterium sp. No. 93-1; NAD-MalDH, NAD-dependent maltose dehydrogenase; NADP-MalDH, NADP-dependent maltose dehydrogenase. were reported. ${ }^{19)}$ The characteristics of NADGlcDH of this strain was interesting from a standpoint of comparison with already reported GlcDHs. This paper deals with the purification and properties of NAD-GlcDH.

\section{MATERIALS AND METHODS}

Culture. An alkalophilic Corynebacterium sp. No. 93-1 was cultured in $600 \mathrm{ml}$ of liquid medium in 2-liters Erlenmeyer flask at $30^{\circ} \mathrm{C}$ for $24 \mathrm{hr}$ on a rotary shaker. The composition of the medium used was as follows: $1 \%$ maltose, $1 \%$ soybean casein, $0.1 \%$ yeast extract, $0.1 \%$ $\mathrm{K}_{2} \mathrm{HPO}_{4}, 0.02 \% \mathrm{MgSO}_{4} \cdot 7 \mathrm{H}_{2} \mathrm{O}$ and $0.2 \% \mathrm{Na}_{2} \mathrm{CO}_{3}$ (sterilized separately).

Enzyme assay. NAD-GlcDH activity was assayed by the method described previously. ${ }^{18)}$

Disc electrophoresis. Disc electrophoresis was performed using $7.5 \%$ polyacrylamide gel at running pH 8.0 . Electrophoresis was carried out at $3 \mathrm{~mA} /$ tube at $5^{\circ} \mathrm{C}$. Protein was stained with Coomassie Brilliant Blue R250. NAD-GlcDH activity was detected by incubation of the gel at room temperature in $100 \mathrm{~mm}$ Tris- $\mathrm{HCl}$ buffer $(\mathrm{pH}$ 9.0 ) with $100 \mathrm{~mm}$ D-glucose, $0.05 \mathrm{~mm}$ phenazinemethosulfate and $0.3 \mathrm{~mm}$ 3-(4,5-dimethyl-thiazolyl)-2,5-diphenyltetrazolium bromide (MTT).

SDS-disc electrophoresis. SDS-disc electrophoresis was 
performed according to Weber and Osborn. ${ }^{20)}$ Electrophoresis was carried out at $8 \mathrm{~mA} /$ tube using $10 \%$ acrylamide gel, containing $0.1 \%$ SDS. Protein was stained with Coomassie Brilliant Blue R250.

Electrofocusing. Electrofocusing was performed using 1\% (v/v) Carrier Ampholine ( $\mathrm{pH} 3.5 \sim 6$ ) and sucrose gradient in a $110 \mathrm{ml}$ column (LKB Produkters) at $1000 \mathrm{~V}$ for $15 \mathrm{hr}$ at $2^{\circ} \mathrm{C}$. After fractionation ( $2 \mathrm{ml} /$ tube), NADGlcCH activity was assayed.

Molecular weight determination by gel filtration on Ultrogel AcA44. The molecular weight of NAD-GlcDH was determined according to Andrews, ${ }^{21)}$ using a column $(1.6 \times 100 \mathrm{~cm})$ of Ultrogel AcA44 which had been equilibrated with $50 \mathrm{~mm}$ phosphate buffer ( $\mathrm{pH} 7.5$ ), containing $10 \% \quad(\mathrm{v} / \mathrm{v})$ glycerol and $1 \mathrm{mM} \quad 2-$ mercaptoethanol.

Uhracentrifugation. Analytical ultracentrifugation was carried out to estimate the sedimentation velocity of NAD-GicDH by a Spinco Model E ultracentrifuge (Beckman Instrument) equipped with a schlieren optic. Protein concentration used was $3.0 \mathrm{mg} / \mathrm{ml}$ in $20 \mathrm{~mm}$ phosphate buffer ( $\mathrm{pH} 7.2$ ).

Protein determination. Protein was measured from absorbance at $260 \mathrm{~nm}$ and $280 \mathrm{~nm}$ according to Layne. ${ }^{22)}$

Chemicals. NAD, NADP, NADH and NADPH were purchased from Kyowa Hakko Kogyo Co. Maltotriose was a gift from Dr. N. Nakamura of Nihon Shokuhin Kako Co. Laminaribiose was a gift from Dr. K. Watanabe of our laboratory. All other chemicals were reagent grade.

\section{RESULTS}

\section{Purification}

All purification procedures were carried out at $5^{\circ} \mathrm{C}$. The enzyme solution was concentrated by a Diaflow membrane PM 10 throughout the purification.

Step. 1. Extraction. Wet cells $(80 \mathrm{~g})$ were suspended in $100 \mathrm{ml}$ of $20 \mathrm{~mm}$ phosphate buffer ( $\mathrm{pH} 7.3$ ), containing $5 \mathrm{~mm}$ 2-mercaptoethanol, $1 \mathrm{~mm}$ EDTA and phenyl-methylsulfonyl-fluoride (PMSF) $(2 \mu \mathrm{g} / \mathrm{ml})$ and disrupted by sonication at $20 \mathrm{kHz}$ for $15 \mathrm{~min}$. The sonicated suspension was centrifuged at $20,000 \times g$ for $20 \mathrm{~min}$, and the cell debris was removed. And unbroken cells were subjected to sonic treatment in the same manner for another three cycles. The cell free extracts obtained were combined $(300 \mathrm{ml})$.

Step 2. Streptomycin-sulfate treatment. The cell free extract was diluted with water to $900 \mathrm{ml}$, and $120 \mathrm{ml}$ of $5 \%$ streptomycin-sulfate solution was added in dropwise. After adjusting $\mathrm{pH}$ to 7.0 with $0.2 \mathrm{~N} \mathrm{NaOH}$ solution, the suspension was allowed to stand for $30 \mathrm{~min}$. The precipitate was removed by centrifugation, and the supernatant solution $(970 \mathrm{ml})$ was obtained.

Step 3. Ammonium sulfate fractionation. Ammonium sulfate fractionation was carried out at $30 \sim 70 \%$ saturation. After standing for an hour, the precipitate was collected by centrifugation and dissolved in a minimal volume of $50 \mathrm{~mm}$ phosphate buffer $(\mathrm{pH} \mathrm{7.3)}$, containing $10 \%(\mathrm{v} / \mathrm{v})$ glycerol, $1 \mathrm{~mm} 2$-mercaptoethanol, $1 \mathrm{~mm}$ EDTA and $1 \mathrm{mM}$ PMSF (Buffer A), and dialyzed overnight against the same buffer. After dialysis, $212 \mathrm{ml}$ of the enzyme solution was obtained.

Step 4. DEAE cellulose column chromatography. The enzyme solution was loaded onto a DEAE cellulose column $(9 \times 40 \mathrm{~cm})$ equilibrated with Buffer A. After washing the column with the same buffer, the enzyme was eluted with a linear gradient of $\mathrm{NaCl}(0 \sim 0.8 \mathrm{M})$. Twenty milliliters of the fraction was collected and the enzyme activity was assayed. As described in the previous paper, ${ }^{19}$ NADMalDH, NADP-MalDH and NAD-GlcDH activities were separated by this chromatography method. The active fractions of NADGlcDH were pooled and concentrated.

Step 5. First gel filtration on Ultrogel AcA44. Concentrated NAD-GlcDH solution was applied to a column $(2.5 \times 100 \mathrm{~cm})$ of Ultrogel AcA44 equilibrated with Buffer A, and it was eluted with the same buffer. Figure 1 shows the elution pattern of NAD-GlcDH in this step. The active fractions (fraction No. $59 \sim 63$ ) were combined.

Step 6. DE 52 Cellulose column chromatog- 


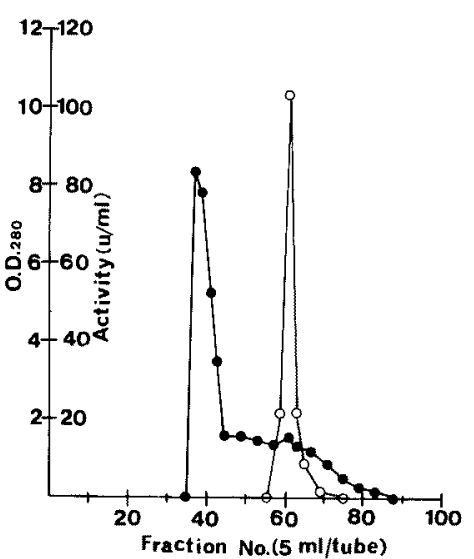

Fig. 1. First Gel Filtration of NAD-GlcDH on Ultrogel AcA44.

NAD-GlcDH activity was assayed by the standard assay method. NAD-GlcDH activity (O); protein

raphy. The enzyme solution was loaded onto a DE 52 cellulose column $(1.2 \times 20 \mathrm{~cm})$, which had been equilibrated with Buffer A. After washing the column with the same buffer, the enzyme was eluted with a linear gradient of $\mathrm{NaCl}(0 \sim 0.8 \mathrm{M})$. The enzyme fractions (fraction No. $20 \sim 26$ ) were combined.

Step 7. Hydroxyl apatite column chromatography. After dialysis of the enzyme solution against $10 \mathrm{~mm}$ phosphate buffer $(\mathrm{pH} 7.3$ ), containing $10 \%(\mathrm{v} / \mathrm{v})$ glycerol, $1 \mathrm{~mm} 2-$ mercaptoethanol and $1 \mathrm{~mm}$ EDTA (Buffer B), the enzyme placed on a Hydroxyl apatite column $(2.5 \times 20 \mathrm{~cm})$ equilibrated with Buffer B. The column was washed with the same

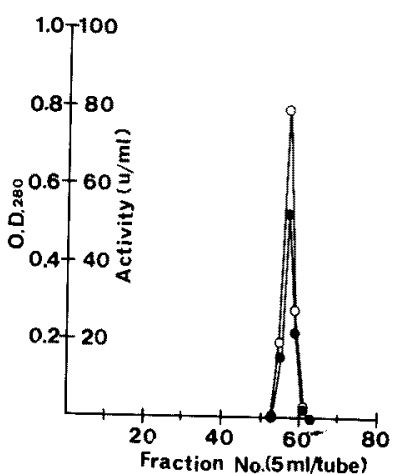

FIG. 2. Second Gel Filtration of NAD-GlcDH on Ultrogel AcA44.

NAD-GIcDH activity was assayed by the standard assay method. NAD-GlcDH activity $(\mathrm{O})$; protein $(0)$

buffer and the enzyme was eluted with a linear gradient of $10 \sim 100 \mathrm{~mm}$ phosphate buffer $(\mathrm{pH}$ 7.3), containing the same contents as Buffer B. The active fractions (fraction No. 40 50) were pooled and concentrated.

Step 8. Second gel filtration on Ultrogel $A C A 44$. The enzyme solution was passed through an Ultrogel AcA44 column $(2.5 \times 100$ $\mathrm{cm}$ ) equilibrated with Buffer $\mathrm{C}$ (excepted PMSF from Buffer A). As shown in Fig. 2, NAD-GlcDH was highly purified. The enzyme fractions (fraction No. 55 59) were combined and concentrated. This preparation was used for the following experiments. A summary of the purification is shown in Table I. In this purification of NAD-GlcDH, we used Blue

Table 1. Summary of the Purtfication of NAD-GlcDH

\begin{tabular}{lcccccc}
\hline & $\begin{array}{c}\text { Total } \\
\text { volume } \\
(\mathrm{ml})\end{array}$ & $\begin{array}{c}\text { Total } \\
\text { activity } \\
\text { (units) }\end{array}$ & $\begin{array}{c}\text { Total } \\
\text { protein } \\
(\mathrm{mg})\end{array}$ & $\begin{array}{c}\text { Specific } \\
\text { activity } \\
\text { (u/mg prot. })\end{array}$ & $\begin{array}{c}\text { Yield } \\
(\%)\end{array}$ & $\begin{array}{c}\text { Purification } \\
(- \text { fold })\end{array}$ \\
\hline Crude extracts & 300 & 3714 & 7560 & 0.491 & 100 & 1 \\
Streptomycin-sulfate treatment & 970 & 3264 & 3735 & 0.874 & 87.9 & 1.78 \\
Ammonium sulfate fractionation & 212 & 3029 & 2078 & 1.46 & 81.6 & 2.97 \\
DEAE cellulose & 754 & 2348 & 1039 & 2.26 & 63.2 & 4.60 \\
Ultrogel AcA44, 1st & 33 & 1913 & 51.8 & 36.9 & 51.5 & 75.2 \\
DE 52 cellulose & 41 & 1861 & 34.0 & 54.7 & 50.1 & 111 \\
Hydroxyl apatite & 63 & 1525 & 15.0 & 102 & 41.1 & 208 \\
Ultrogel AcA44, 2nd & 23 & 924 & 8.70 & 106 & 24.9 & 216 \\
\hline
\end{tabular}


Sepharose CL-6B and 2',5'-ADP Sepharose for affinity chromatography, but the enzyme showed no affinity for these materials.

\section{Homogeneity}

The homogeneity of the purified enzyme was checked by disc electrophoresis and SDSdisc electrophoresis. Figure 3 shows that the preparation was composed of a single component. Activity staining of NAD-GlcCH on the disc gel gave a single band at a location corresponding to the protein band observed. From these results, it was clear the preparation was homogeneous.

\section{Physical properties}

Molecular weight. The molecular weight of NAD-GlcDH was estimated using gel filtration and SDS-disc electrophoresis. Gel filtration on Ultrogel AcA44 column was performed, and the enzyme was eluted at the position of molecular weight 55,000 (Fig. 4). The enzyme was also located at molecular weight 51,000 by SDS-disc gel (Fig. 4). On the basis of these results, NAD-GlcDH was composed of a single peptide chain and no subunit structure was observed.

Isoelectric point. The isoelectric point was determined by the isoelectrofocusing method.

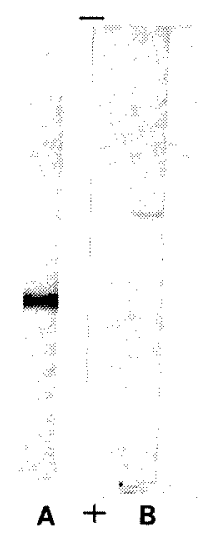

FIG. 3. Disc Electrophoresis and SDS-Disc Electrophoresis.

About $30 \mu \mathrm{g}$ of the enzyme was used, and protein was stained with Coomassie Brilliant Blue R250. A, Disc electrophoresis; B, SDS-disc electrophoresis.

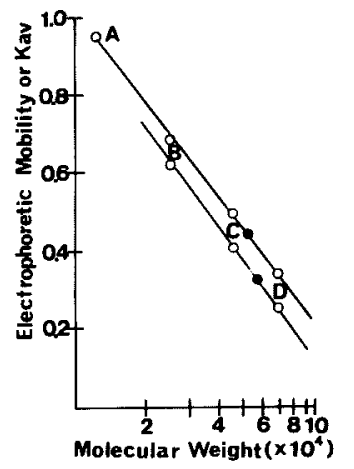

FIG. 4. Molecular Weight Determination of NADGlcDH by Gel Filtration and SDS-Disc Electrophoresis.

The upper line is from the results of SDS-disc electrophoresis, and the lower line is from gel filtration. Standard proteins used were: A, cytochrome $c(12,500)$; B, chymotripsinogen A $(25,000)$; C, ovalbumin $(45,000)$; and $D$, bovine serum albumin $(68,000)$.

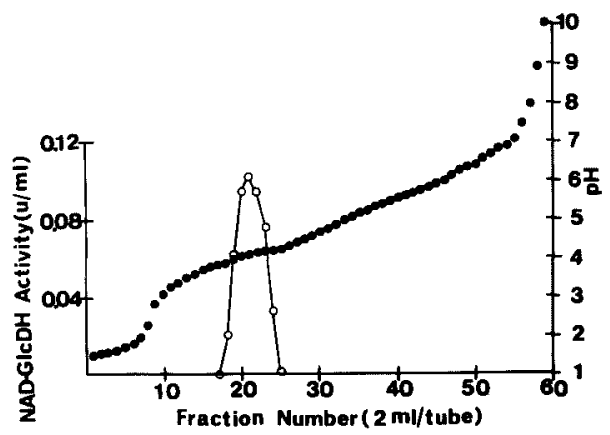

FIG. 5. Determination of Isoelectric Point of NADGIcDH.

About 300 units of the enzyme was used, and NADGlcDH activity was assayed by the standard assay method. NAD-GlcDH activity (O); pH (O).

As shown in Fig. 5, the enzyme activity was found as a single peak, and it was located at pH 4.05. But almost all activity was lost by this procedure.

Ultraviolet spectrum. NAD-GlcDH showed the absorption spectrum of a typical protein, and a prosthetic group was not detected. The maximum absorption existed at $280 \mathrm{~nm}$ and the minimum at $253 \mathrm{~nm}$. The absorption ratio $280 \mathrm{~nm} / 260 \mathrm{~nm}$ was 1.83 at $\mathrm{pH} 7.2$. 
Apparent $S$ value. On ultracentrifugal analysis, a symmetrical peak was observed, and the apparent $S$ value was calculated as 5.0.

\section{Effect of $\mathrm{pH}$}

The optimal $\mathrm{pH}$ of NAD-GlcDH was 9.8 in $50 \mathrm{~mm}$ glycine-NaOH buffer (Fig. 6). The stability of the enzyme at various $\mathrm{pH}$ values was investigated. The enzyme preparation was treated in each buffers for $30 \mathrm{~min}$ at $30^{\circ} \mathrm{C}$, and residual activities were measured. As shown in Fig. 7, NAD-GlcDH was stable at a $\mathrm{pH}$ range from 6 to 8 .

\section{Effect of temperature}

The optimal temperature of NAD-GlcDH was investigated and found around $30^{\circ}$ to $35^{\circ} \mathrm{C}$ (Fig. 8). The thermal stability of the enzyme was examined in the presence or absence of $1 \mathrm{~mm} \mathrm{NAD,} 1 \mathrm{~mm} 2$-mercaptoethanol, $1 \mathrm{~mm}$ D-glucose and $5 \%(\mathrm{w} / \mathrm{w})$ glycerol. The results obtained are shown in Fig. 9. NAD and glycerol provided some protection against heat inactivation. A decrease in enzyme activity was not detected for at least three

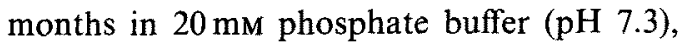
containing $1 \mathrm{~mm} \mathrm{2-mercaptoethanol} \mathrm{and} \mathrm{50 \%}$ (v/v) glycerol at $-20^{\circ} \mathrm{C}$.

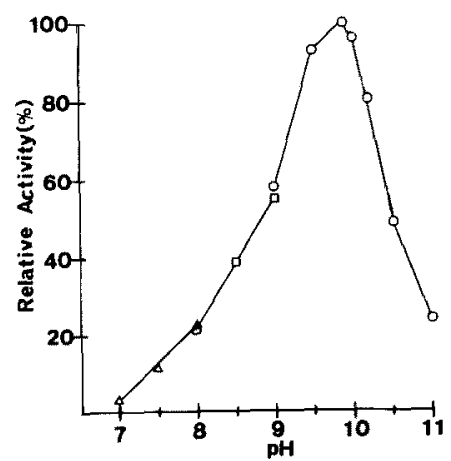

Frg. 6. Optimal pH of NAD-GleDH.

The optimal $\mathrm{pH}$ of NAD-GlcDH activity was in vestigated using the following buffer systems: $\mathrm{pH} 7 \sim 8$, $100 \mathrm{~mm}$ phosphate buffer $(\triangle)$; pH $8 \sim 9,100 \mathrm{~mm}$ Tris$\mathrm{HCl}$ buffer $(\square)$; and pH $9 \sim 11,100 \mathrm{~mm}$ glycine- $\mathrm{NaOH}$ buffer $(O)$.

\section{Substrate specificity}

The substrate specificity of NAD-GlcDH was investigated using $100 \mathrm{~mm}$ of 25 kinds of carbohydrates with NAD or NADP as a cofactor. As summarized in Table II, the enzyme showed oxidation activity on Dglucose, D-xylose, cellobiose and gentiobiose. 2-Deoxy-D-glucose was not effective as a substrate. NAD-GlcDH oxidized cellobiose and gentiobiose, but could not oxidize mal-

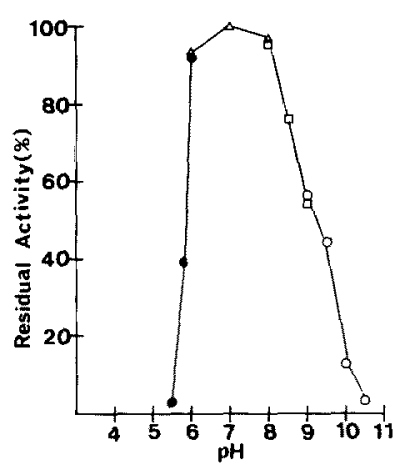

FIG. 7. pH Stability of NAD-GIcDH.

NAD-GlcDH was treated in each buffer for $30 \mathrm{~min}$ at $30^{\circ} \mathrm{C}$. After adjusting $\mathrm{pH}$ to 7.0 with $200 \mathrm{~mm}$ phosphate buffer ( $\mathrm{pH} 7.0$ ), the residual activity was measured by the standard assay condition. The buffer systems used were: pH 5.5 6, $100 \mathrm{~mm}$ succinate buffer (O); pH 6 8, $100 \mathrm{~mm}$ phosphate buffer $(\triangle) ; \mathrm{pH} 8 \sim 9,100 \mathrm{~mm}$ Tris$\mathrm{HCl}$ buffer $(\square)$; and pH $9 \sim 10.5,100 \mathrm{~mm}$ glycine- $\mathrm{NaOH}$ buffer (O).

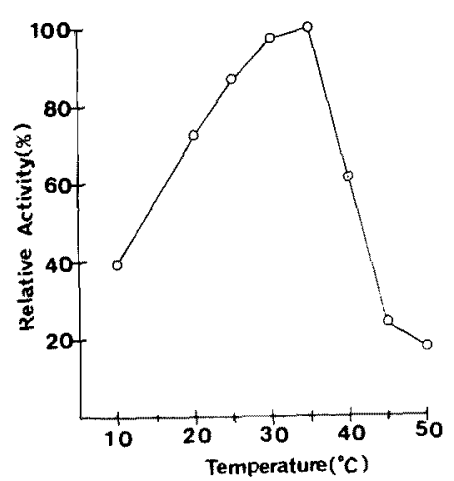

FIG. 8. Optimal Temperature of NAD-GlcDH.

NAD-GlcDH activity was assayed by the standard assay method at various temperatures. 


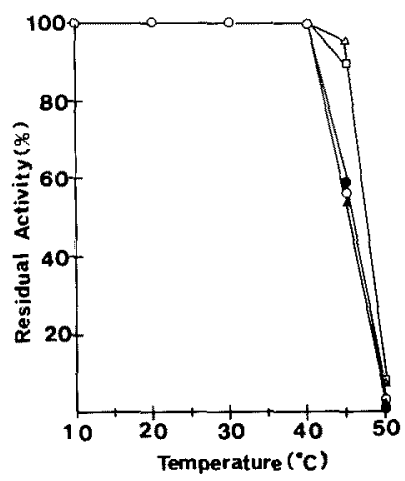

FIG. 9. Thermal Stability of NAD-GlcDH.

NAD-GlcDH was treated at each temperature point for $10 \mathrm{~min}$ in $50 \mathrm{~mm}$ phosphate buffer $(\mathrm{pH} 7.0)$ and the residual activity was measured by the standard assay method. The stabilizing effect of several kinds of reagents on NAD-GlcDH was investigated. None $(\mathrm{O}) ; 1 \mathrm{~mm}$ NAD $(\triangle) ; 1$ mM 2-mercaptoethanol (C); 1 mM D-glucose (A); $5 \%(w / w)$ glycerol $(\square)$.

tose, lactose and melibiose. Cellotriose and laminaribiose were also suitable substrates. Therefore, the velocities at $20 \mathrm{~mm}$ concentration of $\mathrm{D}$-glucose, cellobiose, cellotriose and laminaribiose were compared. Cellotriose was oxidized to the same degree as cellobiose.
NAD was more effective as a cofactor than NADP on all substrates tested.

Effect of concentration of substrates and NAD Lineweaver-Burk analysis was carried out to estimate $\mathrm{Km}$ values for D-glucose, D-xylose, cellobiose and gentiobiose. Figure 10 shows that $\mathrm{Km}$ values for $\mathrm{D}$-glucose, D-xylose, cellobiose and gentiobiose were $51 \mathrm{~mm}, 125 \mathrm{~mm}$, $11 \mathrm{~mm}$ and $3.2 \mathrm{~mm}$, respectively. The same analysis was performed on the concentration effect of NAD, using $100 \mathrm{~mm}$ of D-glucose as substrate. A $K m$ value of $0.44 \mathrm{~mm}$ was obtained.

\section{Effect of various kinds of reagents on NAD-} GlcDH activity

The effect on the activity of various kinds of salts, inhibitors, metal ions, nucleotides, sugar phosphates was examined. The results obtained are summarized in Table III. Of salts tested, $\mathrm{LiCl}$ and $\left(\mathrm{NH}_{4}\right)_{2} \mathrm{SO}_{4}$ showed about $60 \sim 70 \%$ inhibitory activity. On $\mathrm{SH}$ reagents and metal ions, $0.1 \mathrm{mM}$ PCMB, $1 \mathrm{mM} \mathrm{Hg}^{2+}$ and $1 \mathrm{~mm} \mathrm{Ag}{ }^{+}$showed complete inhibition. Nucleotides, such as AMP, ADP, ATP and

\section{TABLE II. Substrate Specificity of NAD-GlcDH}

The assay was carried out by the standard assay method using $100 \mathrm{~mm}$ of substrate (Section A) and $20 \mathrm{~mm}$ of substrate (Section B). The relative reaction velocities of various kinds of substrates were related to D-glucose as $100 \%$ with NAD as a cofactor.

\begin{tabular}{|c|c|c|c|c|c|c|c|}
\hline \multirow{3}{*}{ Substrate } & \multicolumn{5}{|c|}{ Section A } & \multicolumn{2}{|c|}{ Section B } \\
\hline & \multicolumn{2}{|c|}{ Relative rate $(\%)$} & \multirow{2}{*}{ Substrate } & \multicolumn{2}{|c|}{ Relative rate $(\%)$} & \multirow{2}{*}{ Substrate } & \multirow{2}{*}{$\frac{\text { Relative rate }(\%)}{\text { NAD }}$} \\
\hline & NAD & NADP & & NAD & NADP & & \\
\hline D-Glucose & 100 & 1 & D-Mannitol & 0 & 0 & D-Glucose & 100 \\
\hline D-Mannose & 2 & 0 & D-Xylitol & 0 & 0 & Cellobiose & 158 \\
\hline D-Galactose & 6 & 0 & D-Sorbitol & 1 & 0 & Cellotriose & 158 \\
\hline D-Fructose & 9 & 6 & Inositol & 1 & 0 & Laminaribiose & 96 \\
\hline D-Xylose & 44 & 1 & D-Arabinitol & 0 & 0 & & \\
\hline D-Ribose & 4 & 2 & Maltotriose & 4 & 0 & & \\
\hline D-Arabinose & 0 & 0 & L-Rhamnose & 0 & 0 & & \\
\hline Maltose & 6 & 0 & L-Fucose & 0 & 0 & & \\
\hline Lactose & 2 & 0 & 2-Deoxy-D-glucose & 8 & 4 & & \\
\hline Cellobiose & 89 & 2 & Glucose-6-P & 1 & 0 & & \\
\hline Gentiobiose & 86 & 1 & D-Glucosamine & 0 & 0 & & \\
\hline Melibiose & 4 & 0 & NAc-D*glucosamine & 2 & 0 & & \\
\hline Sucrose & 0 & 0 & & & & & \\
\hline
\end{tabular}




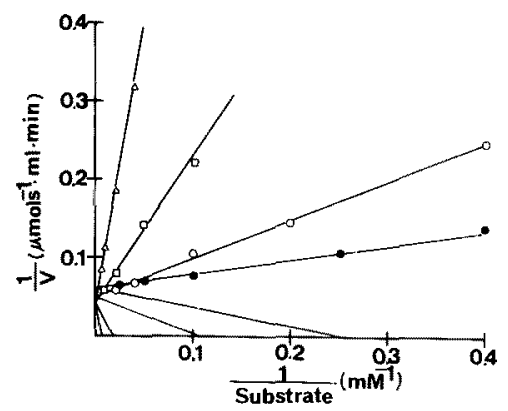

Fig. 10. Lineweaver-Burk Analysis of the Effect of Substrate Concentration on NAD-GlcDH.

The effects of substrate concentrations on the velocities were analyzed by Lineweaver-Burk analysis at $\mathrm{pH} 9.8$. NAD-GlcDH (0.017 unit) in $50 \mathrm{~mm}$ glycine- $\mathrm{NaOH}$ buffer ( $\mathrm{pH} 9.8$ ), and $3 \mathrm{~mm}$ NAD were used for the assay. D-Glucose $(\square)$; D-xylose $(\triangle)$; cellobiose $(O)$; geltiobiose (O).

cAMP, and intermediates of glycolysis, such as G-6-P, F-6-P, FDP and 6-PG, had no effects. $\mathrm{NADH}(0.1 \mathrm{~mm}), \mathrm{NADPH}(0.1 \mathrm{~mm})$ and NADP ( $3 \mathrm{mM}$ ) showed inhibitory activities of about $45 \%, 20 \%$ and $30 \%$, respectively. The effect of 2-deoxy-D-glucose on NAD-GlcDH activity was examined, but it had no effect.
Inhibitory effect of NADH on NAD-GlcDH activity

As described above, NADH inhibited NAD-GlcDH activity. Therefore, the NADH effect was analyzed by a Lineweaver-Burk plot. Using $0.1 \mathrm{~mm}$ or $0.2 \mathrm{~mm} \mathrm{NADH}$, the velocities of the reaction under saturated NAD ( $3 \mathrm{mM}$ ) were compared with that of the control in which D-glucose concentration was changed from $10 \mathrm{~mm}$ to $200 \mathrm{~mm}$. As shown in Fig. 11 (A), NADH acted as a noncompetitive inhibitor of D-glucose with a $K i$ value of 0.11 $\mathrm{mM}$. The same analysis was carried out with saturated D-glucose ( $200 \mathrm{~mm}$ ) with changes in concentration of NAD from $0.1 \mathrm{~mm}$ to $2 \mathrm{~mm}$. Figure 11(B) shows that inhibition was competitive with $K i$ value of $0.048 \mathrm{~mm}$.

\section{Reversibility of reaction}

The velocities of the reverse reaction of this enzyme action were measured at $\mathrm{pH} 7.0$ and 8.0. The assay mixture used was as follows: $0.5 \mathrm{ml}$ of $100 \mathrm{~mm}$ phosphate buffer $(\mathrm{pH} 7.0$ or $8.0), 0.1 \mathrm{ml}$ of $2 \mathrm{mM} \mathrm{NADH}$ solution, $0.1 \mathrm{ml}$ of $1 \mathrm{M}$ glucono- $\delta$-lactone solution and 1.0 unit of NAD-GlcDH in $0.3 \mathrm{ml}$ of $10 \mathrm{~mm}$ phosphate

Table III. EfFect of Various Kinds of Reagents on NAD-GlcDH Activity

\begin{tabular}{|c|c|c|c|c|c|}
\hline Reagents & Concentration & $\begin{array}{c}\text { Activity } \\
(\%)\end{array}$ & Reagents & Concentration & $\begin{array}{c}\text { Activity } \\
(\%)\end{array}$ \\
\hline None & & 100 & $\mathrm{Hg}^{2+}$ & $1 \mathrm{mM}$ & 0 \\
\hline $\mathrm{NaCl}$ & $1 \mathrm{M}$ & 72 & $\mathrm{Ag}^{+}$ & $1 \mathrm{~mm}$ & 1 \\
\hline $\mathrm{KCl}$ & $1 \mathrm{M}$ & 56 & $\mathrm{Mn}^{2+}$ & $1 \mathrm{mM}$ & 84 \\
\hline $\mathrm{LiCl}$ & $1 \mathrm{M}$ & 36 & $\mathrm{Ni}^{2+}$ & $1 \mathrm{~mm}$ & 96 \\
\hline$\left(\mathrm{NH}_{4}\right)_{2} \mathrm{SO}_{4}$ & $1 \mathrm{M}$ & 29 & $\mathrm{Co}^{2+}$ & $1 \mathrm{~mm}$ & 26 \\
\hline Tris & $100 \mathrm{mM}$ & 100 & $\mathrm{Ba}^{2+}$ & $1 \mathrm{mM}$ & 93 \\
\hline EDTA & $10 \mathrm{~mm}$ & 100 & $\mathrm{Fe}^{2+}$ & $1 \mathrm{mM}$ & 59 \\
\hline DTT & $10 \mathrm{~mm}$ & 72 & $\mathrm{Fe}^{3+}$ & $1 \mathrm{mM}$ & 59 \\
\hline DTT & $1 \mathrm{mM}$ & 94 & AMP & $1 \mathrm{~mm}$ & 101 \\
\hline 2-Mercaptoethanol & $10 \mathrm{mM}$ & 90 & ADP & $1 \mathrm{mM}$ & 100 \\
\hline 2-Mercaptoethanol & $1 \mathrm{mM}$ & 100 & ATP & $1 \mathrm{mM}$ & 100 \\
\hline MIA & $10 \mathrm{~mm}$ & 97 & cAMP & $1 \mathrm{mM}$ & 99 \\
\hline $\mathrm{NaF}$ & $10 \mathrm{~mm}$ & 97 & G-6-P & $1 \mathrm{~mm}$ & 101 \\
\hline $\mathrm{KCN}$ & $10 \mathrm{mM}$ & 102 & F-6-P & $1 \mathrm{mM}$ & 100 \\
\hline PCMB & $0.1 \mathrm{~mm}$ & 0 & FDP & $1 \mathrm{~mm}$ & 100 \\
\hline $\mathrm{Zn}^{2+}$ & $1 \mathrm{mM}$ & 92 & 6-PG & $1 \mathrm{mM}$ & 102 \\
\hline $\mathrm{Mg}^{2+}$ & $1 \mathrm{mM}$ & 102 & $\mathrm{NADH}$ & $0.1 \mathrm{~mm}$ & 55 \\
\hline $\mathrm{Cu}^{2+}$ & $1 \mathrm{~mm}$ & 86 & NADPH & $0.1 \mathrm{mM}$ & 81 \\
\hline $\mathrm{Ca}^{2+}$ & $1 \mathrm{mM}$ & 86 & NADP & $3 \mathrm{mM}$ & 67 \\
\hline
\end{tabular}




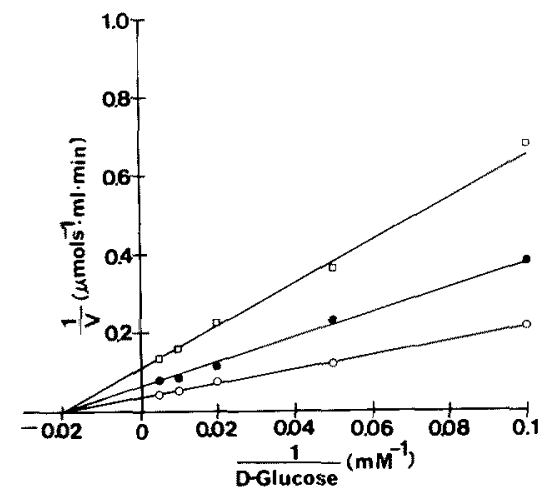

(A)

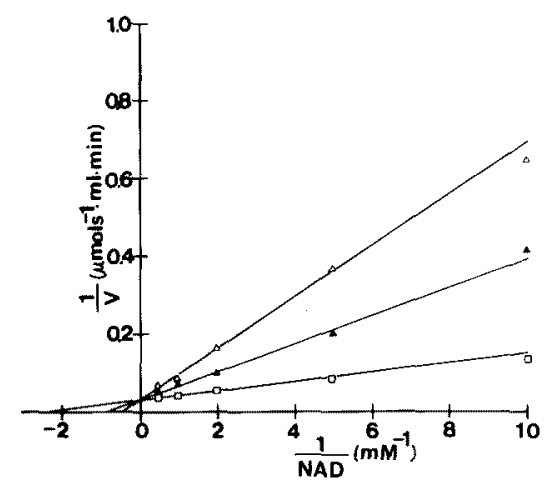

(B)

FIG. 11. Lineweaver-Burk Analysis of the Effect of NADH Concentration on NAD-GlcDH.

(A) The effect was examined with saturated NAD ( $3 \mathrm{mM}$ ). NADH concentrations used were $0.1 \mathrm{~mm}(\mathbf{O})$ and $0.2 \mathrm{~mm}(\square)$. The control sample $(O)$ was assayed by the standard assay condition. NAD-GIcDH activity used was 0.023 unit.

(B) The same analysis was carried out with saturated Dglucose $(200 \mathrm{~mm})$. NADH concentrations used were $0.1 \mathrm{~mm}(\boldsymbol{\Delta})$ and $0.2 \mathrm{~mm}(\triangle)$. The control sample $(\square)$ was assayed by the standard assay condition. NAD-GlcDH used was 0.025 unit.

buffer ( $\mathrm{pH}$ 7.0). A decrease of O.D. $340 \mathrm{~nm}$ was measured at $30^{\circ} \mathrm{C}$, and the velocities observed were compared with the results obtained by oxidative reaction assayed in the same condition using D-glucose and NAD. The velocities of the reverse reaction at $\mathrm{pH} 7.0$ and 8.0 were $2.2 \%$ and $5.9 \%$, respectively, of oxidative reaction.

\section{DISCUSSION}

In previous papers, ${ }^{18,19)}$ we have reported that alkalophilic Corynebacterium sp. No. 93-1 produced NAD-GlcDH, and the enzyme was separated from NAD(P)-MalDH activities by DEAE cellulose column chromatography. The purified NAD-GlcDH was composed of a single peptide chain (M.W. 51,000 55,000). Although several investigators reported on the relationship between enzyme activity and subunit structure of GlcDH, ${ }^{6,7,14,16)}$ we could not detect multiple form of NAD-GlcDH in the cell free extract. The optimal pH (9.8) of our enzyme existed more alkaline region than enzymes so far reported. Our enzyme showed oxidative activity on D-glucose, D-xylose, gentiobiose, cellobiose and laminaribiose with NAD as a cofactor. The enzyme could not oxidize maltose, lactose and melibiose. From these results, we expected that our enzyme had affinity on reducing disaccharides and trisaccharide, which contained glucose residues in the reducing end, and $\beta$-linkage in two or three sugar components. This property was very unique compared with sugar dehydrogenases already known and NAD-MalDH. ${ }^{19)}$ Our enzyme scarcely oxidize 2-deoxy-Dglucose and it could not oxidize D-glucosamine and NAc-D-glucosamine. GlcDH of $B$. megaterium, $^{12,13)}$ B. subtilis ${ }^{15)}$ and Bacillus sp. ${ }^{23)}$ oxidized D-glucose and 2-deoxy-D-glucose in the same degree. Metzger et al. ${ }^{24)}$ examined the properties of $\mathrm{GlcDH}$ in rat liver. The enzyme did not oxidize 2-deoxy-D-glucose and NAc-Dglucosamine, and they reported that the second carbon atom of the hexose molecule must have a hydroxyl group in the glucose configulation to serve as a substrate for GlcDH. Our enzyme had similar substrate specificity to that of rat liver.

The $K m$ value for reactive substrates, for gentiobiose was the smallest, and the next smallest was cellobiose. We expect that these properties show that the enzyme plays a role in the direct oxidation system of disaccharides, such as gentiobiose and cellobiose. The $\mathrm{Km}$ value for D-glucose $(51 \mathrm{~mm})$ 
of our enzyme was almost similar to the value found in $B$. megaterium $(47.5 \mathrm{~mm})^{13)}$ and $B$. subtilis $\left.(55.9 \mathrm{~mm}){ }^{15}\right)$ But it was greater than that of $B$. cereus (7 mM), ${ }^{9}$ Bacillus sp. (4.2 $\mathrm{mm}),{ }^{23)}$ A. suboxydans $(5.3 \mathrm{~mm}){ }^{16)} \mathrm{GlcDH}$ of B. megaterium, ${ }^{4,12,13)}$ B. cereus, ${ }^{11}$ B. subtilis, ${ }^{15)}$ Bacillus sp. ${ }^{23)}$ C. fritschii ${ }^{17)}$ and rat liver used both NAD and NADP as cofactors. The enzyme of $A$. suboxydans ${ }^{16)}$ used only NADP and that of $B$. cereus $^{9)}$ was NAD specific. Our enzyme was NAD specific, and it was similar to that of $B$. cereus. ${ }^{9)}$ The $K m$ value of our enzyme for NAD was $0.44 \mathrm{~mm}$, and it was similar to the $K m$ value of $B$. subtilis $(0.23$ $\mathrm{mm})^{15)}$ and $B$. cereus $\left(0.35 \mathrm{~mm}^{1)} 0.2 \mathrm{~mm}^{9)}\right)$, but it was greater than that of $B$. megaterium $(0.07$ $\mathrm{mM})^{4)}$ and Bacillus sp. $(0.082 \mathrm{~mm}){ }^{23)}$

Sadoff ${ }^{1)}$ reported that GlcDH of $B$. cereus was not inhibited by sulfhydryl group inhibitors and several kinds of metal ions. Pauly and Pfleidere ${ }^{13)}$ reported that GlcDH of $B$. megaterium was not inhibited by sulfhydryl group inhibitors, heavy metal ions and various kinds of chelating reagents. But our enzyme was inhibited completely by PCMB, $\mathrm{Hg}^{2+}$ and $\mathrm{Ag}^{+}$. This result suggested that the sulfhydryl group(s) was contributing to the activity in the same manner as NAD-MalDH. ${ }^{19}$ ) NADH showed a non-competitive type of inhibition to D-glucose in saturated NAD. The enzyme showed a competitive type of inhibition to NAD under saturated D-glucose. These results were the same as those with galactose dehydrogenase in rat liver. ${ }^{25)}$

Acknowledgments. The authors are indebted to Drs. K. Watanabe and N. Nakamura for supplying the chemicals. We wish to thank Mr. M. Chijimatsu of the Institute for his help in ultracentrifugal analysis.

\section{REFERENCES}

1) H. L. Sadoff, "Methods in Enzymology," Vol. 9, ed. by S. P. Colowick and N. O. Kaplan, Academic Press Inc., New York, 1966, p. 92.

2) S. L. Warren, Biochem. J., 109, 811 (1968).

3) W. M. Waites, D. Kay, I. W. Dawes, D. A. Wood, S. C. Warren and J. Mandelstam, Biochem. J., 118, 667 (1970).

4) R. Gavard and C. Comgre, Comptes Rendus, 349, 2243 (1959).

5) C. Prasad, M. Diesterhaft and E. Freese, $J$. Bacteriol., 110, 321 (1972).

6) H. L. Sadoff, J. A. Bach and J. W. Kools, "Spores III," ed. by L. L. Campbell and H. O. Halvorson, Am. Soc. Microbiol., Washington D.C., 1965, p. 97.

7) Y. Hachisuka and K. Tochikubo, J. Bacteriol, 107, 442 (1971).

8) R. H. Doi, H. O. Halvorson and B. Church, ibid., 77, 43 (1959).

9) J. A. Bach and H. L. Sadoff, ibid, 83, 699 (1962).

10) K. F. Bott, ibid., 108, 720 (1972).

11) K. F. Bott and R. Davidoff-Abelson, ibid., 92, 229 (1966).

12) D. Banauch, W. Brummer, W. Ebeling, H. Mets, $H$. Rindfrey, H. Lang, H. Leybold and W. Rick, Z. Klin. Chem. Klin. Biochem., 13, 101 (1975).

13) H. E. Pauly and G. Pfleidere, Hoppe-Seyler's Physiol. Chem., 356, 1613 (1975).

14) H. E. Pauly and G. Pfleidere, Biochemistry, 16, 4599 (1977).

15) Y. Fujita, R. Ramaley and E. Freese, J. Bacteriol., 132, $282(1977)$.

16) K. Okamoto, J. Biochem., 53, 348 (1963).

17) R. Pritchard, A. Beauclerk and A. J. Smith, Biochem. Soc. Trans., 3, 384 (1975).

18) Y. Kobayashi and K. Horikoshi, Agric. Biol. Chem., 44, 41 (1980).

19) Y. Kobayashi and K. Horikoshi, Biochim. Biophys. Acta, 614, 256 (1980).

20) K. Weber and M. Osborn, J. Biol. Chem., 244, 4406 (1969).

21) P. Andrews, Biochem. J., 96, 595 (1965).

22) E. Layne, "Methods in Enzymology," Vol. 3, ed. by S. P. Colowick and N. O. Kaplan, Academic Press Inc., New York, 1957, p. 451.

23) A. Yokota, K. Sasajima and M. Yoneda, Agric. Biol. Chem., 43, 271 (1979).

24) R. P. Metzger, S. S. Wilcox and A. N. Wick, $J$. Biol. Chem., 239, 1769 (1964).

25) P. Cuatrecassas and S. Segal, J. Biol. Chem., 241, $5910(1966)$ 